\title{
INDIVIDUAL DAN ORGANIZATIONAL UNLEARNING: PROPOSISI HUBUNGAN MODERASI CROSS-LEVEL
}

\author{
Henri Dwi Wahyudi \\ Fakultas Ekonomi Dan Bisnis Universitas Muhammadiyah Surakarta \\ Email: hdw122@ums.ac.id
}

\begin{abstract}
Unlearning stripped result old learning to give space for new information and new attitude. Unlearning is undoubtedly for individu or organization to receive new knowledge (herdberg, 1981), increase innovation performance (pighin \&Marzona,2011) and increase the company abbility to facing crisis (Starbuck, 1995), this article give six preposision that connect the literature from micro level and macro level use the mediation variable, multi level moderation to explain the fenomena in organizational behavior that don't have enough support in empirical, individual and organizational unlearning.
\end{abstract}

Keywords: individual unlearning, organizational unlearning, person-organizational fit

\section{PENDAHULUAN}

Kompleksitas persaingan bisnis menuntut organisasi untuk selalu belajar dari setiap perubahan pada lingkungan internal dan eksternalnya. Organisasi tidak hanya dituntut untuk menjadi adaptif, akan tetapi lebih dari itu, organisasi yang berkinerja baik memiliki karakteristik sebagai organisasi pembelajar atau learning organization (Huber, 1981). Pada proses pembelajaran tersebut, organisasi akan membentuk kurva pembelajaran yang menjadi dasar bagi interaksi antara individu, organisasi dan lingkungan nya. Lebih lanjut, guna membangun kapabilitas inovasi, manajer harus menyadari hambatan dalam belajar selain memiliki pemahaman yang luas tentang interaksi antara pembelajaran pada level individu (mikro) dan level organisasi (makro)- dimana kedua level pembelajaran tersebut memiliki anteseden dan konsekuensi yang berbeda namun saling melengkapi. Pada level individu, pembelajaran terkait dengan aspek explicit knowledge dan tacit knowledge (Nonaka \& Takeuchi, 1995). Tacit knowledge sangat melekat pada individu dan hanya dapat dibagikan melalui experience sharing, bersifat simultan dan berlawanan karakteristiknya dengan explicit knowledge. Bagaimana keduanya dikelola, disimpan dan dipertahankan, akan menjadi modal strategis bagi organisasi untuk masuk ke fase perekonomian terkini, yaitu knowledge based economy.

Literatur lain dalam kajian learning organization adalah konsep individual unlearning dan organizational unlearning. Bahwasanya, kedua konsep ini bukan merupakan konsep yang saling bertentangan akan tetapi konsep yang berlangsung secara simultan dalam organisasi pembelajar. Unlearning, lahir dari serangkaian studi yang panjang mengenai bagaimana organisasi dapat gagal, berhasil atau bertahan menghadapi krisis (Hedberg, 1981; Nystrom, Hedberg, and Starbuck, 1976; Starbuck and Hedberg, 1977; Starbuck and Nystrom, 1981; Starbuck, Greve, and Hedberg, 1978). Unlearning muncul sebagai elemen penting akibat terjadinya perubahan dan inovasi dalam organisasi. Topik unlearning cukup banyak dikaji dalam literatur pembelajaran orang dewasa, literatur pembelajaran organisasional dan literatur manajemen pengetahuan. Meski demikian, dari sejumlah besar penelitian tentang organizational learning, sangat sedikit yang diketahui tentang konseptualisasi dan operasionalisasi dari organizational unlearning. Apakah individual unlearning dan organizational unlearning merupakan konsep yang sama ? jika tidak, dimanakah batas keduanya?

Tujuan penulisan artikel ini adalah melakukan telaah literatur unlearning guna 
menyusun proposisi yang dapat menjelaskan anteseden, faktor pemoderasi/ pemediasi dan konsekuensi unlearning. Artikel terbagi menjadi empat bagian, yaitu pendahuluan, telaah literatur dan penyusunan proposisi, saran bagi penyusunan disain penelitian, dan kesimpulan. Artikel ini diharapkan dapat bermanfaat secara teoritis bagi kajian dalam perilaku organisasional yang berkaitan dengan ketidakpastian dan perubahan (seperti kreativitas dan inovasi), dan perilaku organisasi pada situasi krisis.

\section{TELAAH LITERATUR DAN PENYUSUNAN PROPOSISI}

\section{Pengertian Unlearning}

Dari berbagai literatur yang berkaitan dengan unlearning, sejumlah definisi telah disusun. Menurut Hedberg (1981) dalam Becker (2005), pengetahuan tumbuh, dan sekaligus menjadi usang karena terjadinya perubahan. Proses memahami melibatkan, belajar dari pengetahuan baru dan membuang pengetahuan yang usang dan menyesatkan. Proses "membuang" inilah yang disebut Hedberg (1981) sebagai unlearning. Newstrom (1983) dalam Becker (2005) mendefinisikan unlearning sebagai proses mengurangi atau menghilangkan pengetahuan yang sudah ada sebelumnya atau kebiasaan yang akan menjadi penghalang besar untuk belajar pengetahuan baru. Pada pengertian yang serupa, Prahalad dan Bettis (1986) dalam Becker (2005) mendefinisikan unlearning sebagai proses dimana perusahaan menghilangkan logika dan perilaku yang lama, dan meyediakan ruang bagi yang baru. Akhirnya, Starbuck (1996) menyatakan unlearning sebagai proses yang menunjukkan bahwa seseorang dalam situasi tertentu (misal: dalam situasi krisis) seharusnya tidak lagi bergantung pada keyakinan dan metode mereka saat ini.

Semua definisi di atas mengakui potensi pengetahuan yang ada berikut perilaku yang dapat mengganggu belajar. Oleh karena itu, unlearning nampaknya sangat berperan dalam proses memperoleh pengetahuan dan perilaku baru. Lebih lanjut, pada rentang definisi, terkadang definisi dibuat untuk unlearning dihadapi oleh individu, dan lainnya mengacu khusus untuk organisasi. Definisi ini adalah serupa, bahwa mereka umumnya mengakui unlearning sebagai proses bukan peristiwa diskrit dan, kedua, mereka juga mengakui keterkaitan yang erat antara belajar atau memperoleh pengetahuan baru, dan unlearning. Dapat dikatakan bahwa membuat perbedaan antara belajar dan unlearning tidak diperlukan. Namun, setidaknya beberapa literatur di bidang pembelajaran khusus, tidak mengakui keberadaan dari pengetahuan yang telah ada sebelumnya dan potensi dampak pada proses pembelajaran. Kurangnya pengakuan atas hasil pembelajaran sebelumnya disebut oleh Newstrom (1983) sebagai clean slate fallacy - yang berasumsi bahwa peserta didik adalah kain yang bersih atau kapal kosong yang menunggu untuk memperoleh pengetahuan baru tanpa gangguan belajar sebelumnya. Oleh karena itu, harus diakui bahwa ada perbedaan jelas antara proses unlearning dan belajar, meskipun mereka mungkin terjadi secara bersamaan. Hal ini juga menekankan bahwa unlearning tidak harus dilihat sebagai tujuan itu sendiri. Alasan utama untuk mendorong atau terlibat dalam unlearning adalah untuk memungkinkan masuknya pengetahuan atau perilaku baru, dan sebagai sarana untuk membantu pembelajaran, inovasi dan perubahan. Secara umum, unlearning didefinisikan sebagai proses dimana individu dan organisasi mengakui dan melepaskan pengetahuan lama sebelum belajar untuk mengakomodasi informasi dan perilaku yang baru.

Pandangan alternatif mengenai unlearning diajukan oleh Klein (1989) dalam Becker (2005) yang mengajukan a parenthetic model of unlearning. Klein berargumen bahwa pengetahuan lama tidak dihapus, tetapi disimpan untuk situasi di mana diyakini bahwa pengetahuan baru tidak berlaku. Oleh karena itu, disarankan bahwa keputusan yang dibuat oleh individu berdasarkan konteks situasi. Klein percaya bahwa individu selalu mempelajari cara-cara baru dalam merespon situasi tertentu daripada unlearning untuk respon tertentu. Untuk dapat terus tumbuh dan berkembang maka penting untuk mempelajari metode baru sebagai bentuk respon atas situasi tertentu. Jika bertindak demikian, maka individu harus fokus pada perubahan referensi, pola pikir atau tindakan. Sementara itu, Klein juga berargumen bahwa fokus hanya pada 
unlearning juga tidak diperlukan; pada proses perbaikan, peningkatan dan pertumbuhan, penting bagi individu dan organisasi untuk mengenali kebiasaan, pengetahuan dan /atau perilaku sebelumnya yang tidak lagi optimal dan kemudian melepaskan mereka agar dapat memperoleh pandangan yang baru (Nystrom \& Starbuck 1984).

\section{Emotional Intellegence dan Individual Unlearning}

Mayer and Salovey mendefinisikan emotional intelligence (EQ) sebagai kemampuan untuk mengelola emosi dan menggunakannya untuk meningkatkan kinerja yang berkaitan dengan kognitif, dan secara efektif mengatur emosi. Individu yang memiliki EQ adalah individu yang efektif dalam hubungan interpersonal dan selanjutnya mereka akan memperoleh psychological safety (Carmeli, Yitzhak-Halevy, and Weisberg, 2009; Mayer, Caruso, and Salovey, 1999 dalam Lee, 2013). Lebih lanjut, Gardner (1993) mendefenisikan EQ sebagai kemampuan (ability) untuk menyelesaikan masalah atau menemukan hal-hal yang memiliki nilai pada lingkungan dengan setting kultur yang berbeda. EQ juga berfungsi sebagai katalis dalam proses pembelajaran karena EQ memampukan individu untuk memahami, mengelola dan menggunakan emosinya untuk memutuskan perilaku tertentu. Argumen tersebut menjadi dasar bagi penyusunan proposi, sebagai berikut:

Proposisi 1: kecerdasan emosional atau emotional intelligence (EQ) berpengaruh positif pada individual unlearning.

\section{Organizational Memory dan Organizational} Unlearning

Stein (1995) mendefinisikan
organizational memory (OM) sebagai
kemampauan organisasi untuk memper-
tahankan dan mentransmisikan informasi dari
masa lalu kepada anggota organisasi di masa
depan. Stein juga menekankan bahwa OM
memiliki implikasi dan hubungan langsung
dengan learning dan unlearning. Kekuatan
OM terletak pada ketersediaan tangible
(misal: Standar Operating and Procedure)
dan intangible asset (misal: organizational

climate), sebagaimana dinyatakan oleh Levit dan March (1988) dalam Becker (2005): ...how organizations encode, store, and retrieve the lessons of history despite the turnover of personnel and the passage of time. Berdasar penjelasan tersebut, maka justifikasi bahwa explicit knowledge dan tacit knowledge telah dikelola dengan baik dalam organisasi turut menentukan pembentukan OM dan kemampuan organisasi melakukan unlearn. Argumen tersebut menjadi dasar bagi penyusunan proposi, sebagai berikut:

\section{Proposisi 2: organizational memory berpengaruh positif pada organizational unlearning.}

\section{Person-Organization Fit sebagai Variabel Moderasi}

Kristoff (1996) mendefinisikan person-environment fit (PE FIT) sebagai kompatibilitas antara individu dan organisasi, yang dapat terjadi manakala: (a) setidaknya salah satu pihak memenuhi kebutuhan pihak yang lain; (b) kedua belah pihak saling berbagi karakteristik fundamental yang serupa; (c) keduanya. Lebih lanjut, menurut Kristof-Brown, et al (2005), melakukan meta analisis dan meringkas temuan empiris, menyimpulkan bahwa kesesuaian atau fit antara person - environment adalah konsep yang bersifat multi dimensi, meliputi: personvocation fit ( $P V$ fit), person-organization fit (PO fit), person-job fit (PJ fit), person-group fit (PG fit), dan person-supervisor fit (PS fit). Dimensi fit yang berbeda dapat menjadi pemediasi bagi variabel yang berbeda pula. Beberapa teori menghubungkan PE Fit dengan sikap dan perilaku di tempat kerja, antara lain Theory of Work Adjustment (Dawis \& Lofquist, 1984) yang menyatakan bahwa PE Fit mencerminkan tingkat penyesuaian antara pemenuhan kebutuhan biologi dan psikologi pekerja oleh organisasi dan pemenuhan kebutuhan organisasioleh kemampuan pekerja. Pemenuhan ini menghasilkan kepuasan kerja yang selanjutnya dapat mempengaruhi turnover. The Fit Model (Schneider, 1975, 2001 dalam Miron, Erez, \& Naveh, 2004) juga menyatakan bahwa individu dapat mengaktualisasikan potensinya ketika budaya organisasi kongruen dengan nilai, minat dan 
kapabilitas kerja mereka. Contohnya, budaya organisasi yang dapat menumbuhkan inovasi adalah budaya yang memungkinkan karyawan yang kreatif untuk mewujudkan kreativitas tersebut pada kinerjanya.

Ketika individu berada dalam lingkungan kerja yang sesuai dengan tipe kepribadian, kemampuan maupun belief maka individu tersebut dapat mengembangkan potensi dirinya. Tingkat kesesuaian yang tinggi antara individu dengan organisasi akan memperkuat hubungan EQ dengan individual unlearning.

Proposisi 3: person- organization fit memoderasi hubungan kecerdasan emosional atau emotional intelligence (EQ) dan individual unlearning

Ketika organisasi memiliki anggota dengan tipe kepribadian, kemampuan maupun belief yang dibutuhkan, maka organisasi dapat mencapai tujuannya secara efektif dan efisien. Tingkat kesesuaian yang tinggi antara organisasi dengan individu akan memperkuat hubungan organizational memory dan organizational unlearning.

Proposisi 4: person- organization fit memoderasi hubungan organizational memory dan organizational unlearning

\section{Individual Unlearning dan Creative Performance}

Telah banyak dinyatakan dalam literatur perilaku organisasional, bahwa meningkatkan performa kreatif individu adalah sebuah langkah penting jika organisasi ingin memperoleh keunggulan kompetitif (Amabile, 1988; Devanna \& Tichy, 1990; Kanter, 1983; Shalley, 1995 dalam Oldham dan Cumming, 1996). Ketika individu dapat menunjukkan performa kreatifnya, maka mereka akan menghasilkan produk- yang memiliki keterbaruan dan manfaat, ide, atau prosedur yang membuat organisasi dapat terus menginisiasi dan mengimplementasikannya (Amabile, 1988; Staw, 1990; Woodman, Sawyer, \& Griffin, 1993 dalam Oldham dan Cumming, 1996). Inisiasi dan implementasi produk ini, memampukan organisasi untuk merespon setiap kesempatan, sehingga mereka dapat beradaptasi, tumbuh dan bersaing (Kanter, 1983, 1988; March \& Simon, 1958; Van de Ven, 1986; Van de Ven \& Angle, 1989 dalam Oldham dan Cumming, 1996).

Proposisi 5: individual unlearning memediasi hubungan Emotional Intelligence dan creativity

\section{Organizational Unlearning dan Innovative Performance}

Berdasar Fit Model, innovative performance adalah produk cultural dan karakteristik individu (Scott \& Bruce, 1994). Hal yang serupa, kualitas adalah produk dari karakteristik individu yang kongruen dengan budaya yang beorientasi kualitas dan efisiensi adalah produk dari budaya yanng berorientasi hasil atau outcome yang juga dikombinasikan dengan karakteristik individu. Kurang kongruennya individu yang kreatif dengan lingkungannya dapat menghambat innovative performance. Cultural atau budaya organisasi, adalah karakter kuat yang melekat pada organisasi yang dibangun secara filosofis dan historis sebagai pembeda dengan organisasi lainnya. Sebagai produk kognitif, budaya juga merupakan hasil dari pembelajaran organisasi

\section{Proposisi 6: organizational unlearning memediasi hubungan organizational memory dan organizational unlearning}




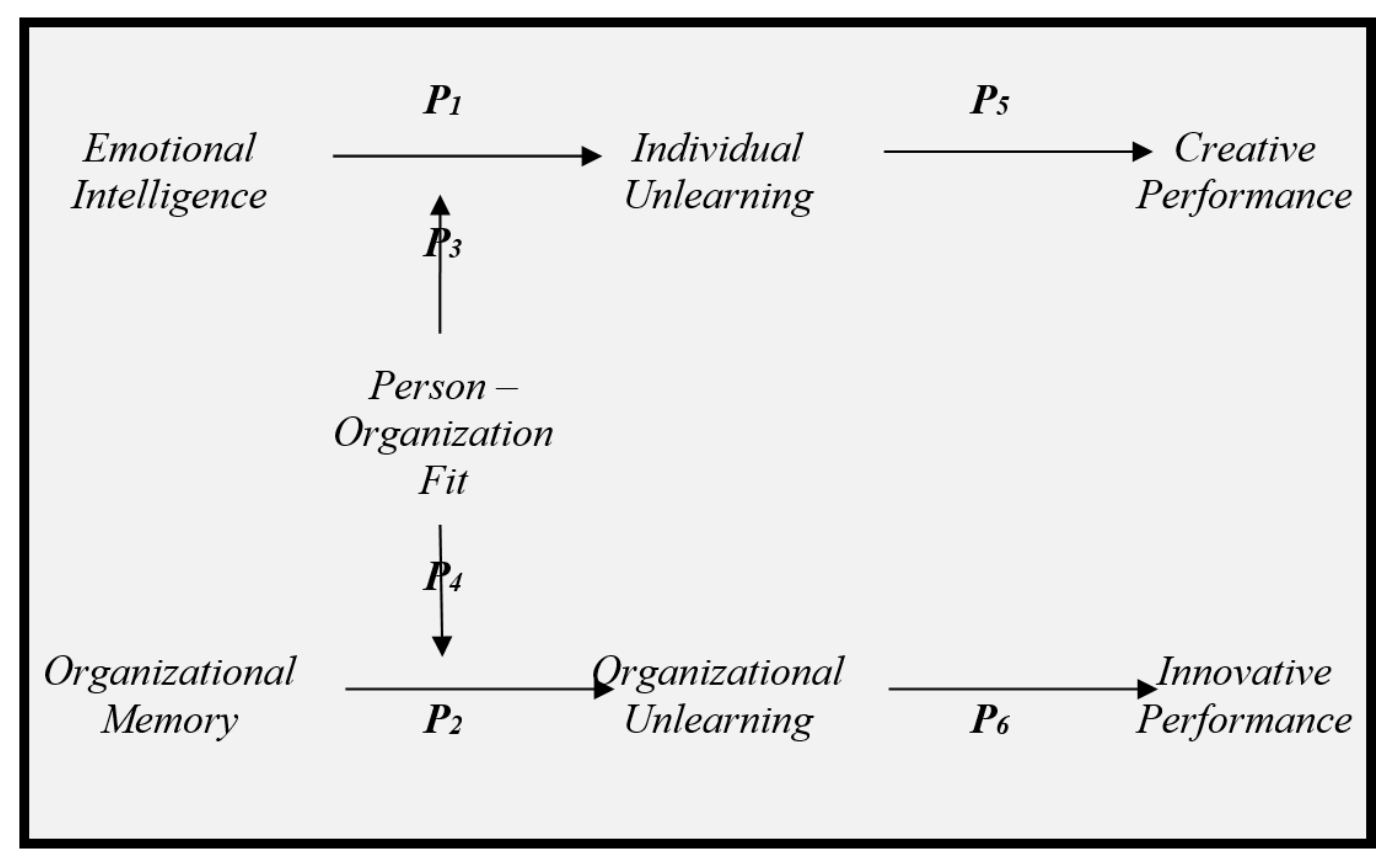

Gambar 1. Kerangka Berpikir Teoritis

\section{SARAN BAGI PENYUSUNAN DISAIN PENELITIAN}

\section{Variabel Mediasi/ Moderasi Multi Level}

Analisis hubungan mediasi adalah metode yang dapat membantu para peneliti memahami mekanisme yang mendasari fenomena yang mereka pelajari. Dasar kerangka hubungan mediasi melibatkan tiga variabel sistem di mana sebuah awal variabel bebas mempengaruhi variabel mediatsi, yang pada gilirannya, mempengaruhi suatu variabel hasil (Baron \& Kenny, 1986). Tujuan dari analisis mediasi adalah untuk menentukan apakah hubungan antara variabel awal dan hasil ini disebabkan, seluruhnya atau sebagian, oleh variabel mediator. Analisis mediasi dapat diterapkan di berbagai macam situasi penelitian eksperimen dan nonexperimen, termasuk penelitian laboratorium dan studi lapangan. Lebih lanjut, analisis mediasi sangat berguna dalam penelitian yang bertujuan melakukan pencegahan, di mana memungkinkan peneliti untuk mengeksplorasi intervensi yang diinginkan.

Analsis mediasi dan moderasi dapat diterapkan pada level analisis yang berbeda yang disebut sebagai multilevel mediational/ moderational modeling. Kelebihan model ini terletak pada fleksibilitasnya yang memungkinkan peneliti untuk menguji hubungan mediasi/ moderasi pada kelompok sampel berjenjang dengan memperhatikan pengaruh variabel secara individu maupun secara agregat. Proposisi di atas dapat diuji menggunakan multi level random coefficient modeling yang diajukan oleh Hofman, Griffin, Gavin (2000) dalam Zohar dan Luria (2005). Pada studinya tentang safety climate, Zohar dan Luria (2005) mengacu prosedur Blise (2002) dan Singer (1998) menggunakan SAS Proc Mixed (Littell, Millken, Stroup, Wolfinger, 1996) yang dapat menguji efek mediasi atau moderasi pada hubungan multi level.

\section{Penyusunan Konstruk}

Keterbatasan hasil studi empiris, kurang memungkinkan peneliti untuk mereplikasi konstruk yang tersedia. Guna mensiasati hal tersebut, pengujian proposisi dalam artikel ini dapat mengikuti prosedur yang dilakukan oleh Lankau \& Scandura (2002) yaitu melakukan studi pendahuluan yang bersifat kualitatif dengan cara interview dan telaah literatur. Untuk menguji validitas konstruknya, peneliti dapat melakukan serangkaian uji validitas untuk menentukan validitas isi, validitas konvergen dan validitas diskriminan, antara lain menggunakan multi trait multi method (MTMM). 


\section{KESIMPULAN}

Meski pengertian unlearning telah banyak ditulis, studi empiris pada topik ini belum terlalu banyak. Artikel yang lebih baru ditulis oleh para praktisi dan konsultan yang didasarkan pada pendapat dan pengalaman mereka dalam organisasi, penelitian lebih kuat di daerah ini akan membantu baik dukungan atau disconfirming banyak asumsi, rekomendasi, dan teori-teori ditawarkan berkaitan dengan unlearning

Pengetahuan tumbuh, dan sekaligus menjadi usang karena perubahan realitas. Memahami melibatkan kedua belajar pengetahuan baru dan membuang usang dan pengetahuan menyesatkan

\section{REFERENSI}

Amabile T M. (1988). A Model of Creativity and Innovatioon in Organizations. Research in Organizational Behavior, 10.

Baron, R.M., Kenny, D.A., 1986. The moderator-mediator variable distinction in social psychological research: Conceptual, strategic, and statistical considerations. Journal of personality and social psychology, 51 (6)

Becker, K. L. (2005). Individual and organisational unlearning: directions for future research. International Journal of Organisational Behaviour, 9(7), 659670.

Lankau, M. J., \& Scandura, T. A. (2002). An investigation of personal learning in mentoring relationships: Content, antecedents, and consequences. Academy of Management Journal, 45(4), 779-790.
Lee , Li-Yueh. (2013). The Antecedents Of Innovation Climate: Cross-Level Mediation Perspectives. Proceeding Of 2013 International Conference In Technology Innovation And Industrial Management.

Miron, Ella, Miriam Erez, And Eitan Naveh. (2004). Do Personal Characteristics And Cultural Values That Promote Innovation, Quality, And Efficiency Compete Or Complement Each Other?. Journal Of Organizational Behavior. 25, 175-199.

Nystorm, PC \& Starbuck, WH. (1984). To avoid crisis, Unlearn. Organizational Dynamics, 12(4), 53.

Pighin, \& Maurizio Anna Marzona. (2011), Unlearning/Relearning In Processes Of Business Information Systems Innovation. Journal Of Information And Organizational Sciences. 35 (1), 59-72

Oldham, Greg R. \& Anne Cumming. (1996). Employee Creativity: Personal And Contextual Factors At Work. Academy Of Management Journal. Vol. 39. No. 3. 607-634.

Schein E.H., (2006), From Brainwashing to Organizational Therapy: a Conceptual and Empirical Journey in Search of 'Systemic' and a General Model of Change Dynamics", in Organization Studies 27/2, SAGE Publications, London, UK

Zohar, Dov., \& Gil Luria. (2005). Multilevel model on safety climate: Cross-level Relationship between organization and group-level climates. Journal of Applied Psychology, 90(4), 616-628. 